Atualidades de Pesquisa

\title{
PARA UMA ETIOLOGIA DA RENÚNCIA AO PROFESSAR: ALGUNS APANHADOS DA CORTE AO NEOLIBERALISMO NO BRASIL
}

Tese de doutorado no Programa de Pós-Graduação em Educação da Faculdade de Educação da Universidade de São Paulo (FEUSP)

\author{
Autor \\ Ricardo Dias Sacco \\ Orientador \\ Prof. Dr. Leandro de Lajonquière \\ (FEUSP)
}

Banca examinadora

Profa. Dra. Margareth Diniz (Universidade Federal de Ouro Preto), Prof. Dr. Daniel Revah (Universidade Federal de São Paulo), Prof. Dr. Douglas Emiliano Batista (Universidade lbirapuera), Profa. Dra. Denice Barbara Catani (FEUSP) 
$\mathbb{N}$

ão é costume discordar de que a vida profissional do professor de educação básica no Brasil seja desprestigiada, mal remunerada e que não sejam encontradas condições mínimas necessárias para seu exercício. Em contrapartida, espera-se que não seja requisitado grande investimento pessoal do professor, pelo fato de sua ação supostamente ser resultado de um domínio estritamente metodológico. Essas imagens habitam o seio de um discurso consolidado sobre o professar que não está isento de um programa de qualificação e desqualificação do outro, pois as mesmas condições que afastam alguns professores fazem que outros se enunciem por sua transposição. Isso realoca a questão para além do discurso hegemônico de toda sorte de precariedades e desprestígios da escola ou da existência de um mal-estar propriamente docente.

Destarte, questionar por que a maioria dos sujeitos que ainda hoje procuram a formação de professor para o ensino fundamental não assume um lugar para exercer sua profissão, de início, implica romper com o apontamento de uma instância conclusiva de renúncia. O trabalho propõe uma nova forma de escuta, psicanalítica, de alguns registros históricos da educação básica brasileira. 